\title{
Nutrient Omission Effects on Growth and Nutritional Status of Seedlings of Assai Palm (Euterpe oleracea Mart.) var. Pai d'égua in Clayey Oxisol
}

\author{
Fábio R. Araújo ${ }^{1}$, Ismael de J. M. Viégas ${ }^{2}$, Diocleia A. S. Silva ${ }^{2}$, Jessivaldo R. Galvão ${ }^{2}$, Dágila M. Rodrigues ${ }^{2}$, \\ Mário L. da Silva Júnior ${ }^{2}$, Fernando S. Santos ${ }^{2}$, Tiago K. M. Yakuwa², Antonio D. L. Paraense ${ }^{2}$ \\ \& Pedro S. da S. Campos ${ }^{2}$ \\ ${ }^{1}$ Instituto de Estudos em Desenvolvimento Agrário e Regional, Universidade Federal do Sul e Sudeste do Pará, \\ Marabá, PA, Brazil \\ ${ }^{2}$ Institute of Agricultural Sciences, Universidade Federal Rural da Amazônia, Belém, Pará, Brazil \\ Correspondence: Jessivaldo R. Galvão, Institute of Agricultural Sciences, Soil Department, Universidade Federal \\ Rural da Amazônia, Tancredo Neves, No 2501, Montese, Belém, State of Pará, Brazil. Tel: 55-919-8842-1133. \\ E-mail: jessi.galvao50@gmail.com
}

Received: January 14, 2019

doi:10.5539/jas.v11n6p510
Accepted: March 2, 2019 Online Published: May 15, 2019

URL: https://doi.org/10.5539/jas.v11n6p510

\begin{abstract}
In order to evaluate the growth, dry mass production, contents and accumulation of macro-and micronutrients in seedlings of assai palm (variety Pai d'égua) in clayey Oxisol we conducted a greenhouse experiment based on the missing element technique. The experimental design was completely randomized with 15 treatments in five replicates. The treatments were: complete fertilizer with liming (complete); no fertilizer and no liming (control); complete fertilization with lime but with the individual omission of nitrogen, phosphorus, potassium, calcium, calcium without lime, magnesium, magnesium without lime, sulfur, boron, copper, manganese and zinc. The following variables were analyzed: plant height, stipe diameter, leaf dry mass, stipe dry mass, and content and accumulation of nutrients in the leaves. The singly omission of $\mathrm{N}, \mathrm{P}$ and $\mathrm{Mg}$ has limited the height of the assai palm. The following singly omissions in decreasing order: $\mathrm{N}>\mathrm{K}>\mathrm{Mg}$ affected the production of leaf dry mass, while the leaf area was restricted by the individual omissions, in order: $\mathrm{N}>\mathrm{P}>\mathrm{K}$. Plant development as measured by relative growth of the aerial part is affected by the lack of $\mathrm{P}>\mathrm{K}>\mathrm{N}>\mathrm{Mg}$ with an average reduction of $61.9 \%$. The nutrients most required by assai palm follow the order: $\mathrm{N}>\mathrm{K}>\mathrm{Ca}>\mathrm{Mg}>\mathrm{P}>\mathrm{Mn}>$ $\mathrm{Zn}>\mathrm{B}>\mathrm{Cu}>\mathrm{S}$.
\end{abstract}

Keywords: missing element technique, macronutrients, content of nutrients

\section{Introduction}

Assai palm (Euterpe oleracea Mart.) is a native palm tree of Amazon Forest and is distributed in the lower Amazon in the Brazilian states of Maranhão, Tocantins and Amapá, reaching the Guianas and Venezuela to the north. It is well known for being abundant and producing fruit that serves as food for local people and being the main source for the palm heart agribusiness in Brazil (Menezes et al., 2008).

The majority of commercial plantations of assai palm are on terra firme (upland) soils in Amazonian regions dominated by low natural fertility and yellow latosols (Oxisols), thus nutrients need to be provided through fertilization in order to increase yields (Viégas et al., 2004). Palm Trees require a large amount of nutrients for both vegetative growth and reproduction, and an adequate supply of fertilizer can promote greater initial growth prior to the reproductive stage (Bovi et al., 2002).

The macronutrients interfere in the production of young plants of assai palm dry mass in the following order: $\mathrm{K}>\mathrm{Mg}>\mathrm{P}>\mathrm{N}>\mathrm{Ca}>\mathrm{S}$ (Haag et al., 1992; Oliveira et al., 2002). Thus, the evaluation of fertility can help to determine which nutrients are most limiting to a plants development (Viégas et al., 2004). In this context, the missing element technique evaluates the nutritional requirements of crops and is an efficient tool for acquiring information about the nutrients that can limit plant growth (Laviola \& Dias 2008; Miranda et al., 2010). 
Therefore, this work aimed to evaluate growth, dry mass production, and content and accumulation of macroand micronutrients in assai palm seedlings of the variety BRS-Pai d'égua growing in clayey Oxisol under the effect of the omission of nutrients.

\section{Material and Methods}

The experiment was conducted under the conditions of the greenhouse at Universidade Federal Rural da Amazônia, Belém city, State of Pará-eastern Amazon. The substrate used was clayey-textured Oxisol (Embrapa, 2013) collected in the municipality of Paragominas, State of Pará, at a depth of 0 to $30 \mathrm{~cm}$, whose chemical characterization is found in Table 1 .

Table 1. Chemical analysis of the clayey Oxisol, at a depth of 0 to $30 \mathrm{~cm}$, used in the experiment

\begin{tabular}{|c|c|c|c|c|c|c|c|c|c|c|c|c|c|c|}
\hline $\mathrm{pH}$ & M.O. & $\mathrm{P}$ & $\mathrm{K}^{+}$ & $\mathrm{S}$ & B & $\mathrm{Cu}$ & $\mathrm{Mn}$ & $\mathrm{Zn}$ & $\mathrm{Ca}^{2+}$ & $\mathrm{Mg}^{2+}$ & $\mathrm{Al}^{+3}$ & $\mathrm{H}+\mathrm{Al}$ & SB & $\mathrm{V}$ \\
\hline $\mathrm{H}_{2} \mathrm{O}$ & $\mathrm{g} \mathrm{dm}^{-3}$ & ----- & 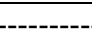 & - & $\mathrm{dm}^{-3}$ & & & --- & & 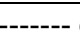 & $\mathrm{nol}_{\mathrm{c}} \mathrm{dn}$ & & --- & $\%$ \\
\hline 4.15 & 5.96 & 3.84 & 56.16 & 28.07 & 0.31 & 1.09 & 89.27 & 2.17 & 4.80 & 1.40 & 0.20 & 5.64 & 6.34 & 52.95 \\
\hline
\end{tabular}

Note. $\mathrm{pH}$ : determined using a glass electrode placed in a 1:2.5 soil to liquid suspension; $\mathrm{Ca}$ and $\mathrm{Mg}$ : determined by atomic absorption, extraction with $\mathrm{KCl}$ at $1 \mathrm{~N}$; P: extracted with a solution of $\mathrm{H}_{2} \mathrm{SO}_{4}+\mathrm{HCl} 0.025 \mathrm{~N}$, measured with a spectrophotometer (wavelength of $660 \mathrm{~nm}$ ); K: determined by flame photometery; Al: titration with $\mathrm{NaOH} 0.025 \mathrm{~N}$.

The experimental design was completely randomized with 15 treatments in five replicates with each pot corresponding to an experimental plot. The treatments were: complete (fertilization with all of the nutrients plus lime), complete ${ }^{\text {-lime }}$ (complete fertilization without lime), control (without fertilizer and without lime) and complete fertilization with lime but with the omission of nitrogen $(-\mathrm{N})$, with the omission of phosphorus (-P), potassium $(-\mathrm{K})$, calcium $(-\mathrm{Ca})$, calcium without lime $\left(-\mathrm{Ca}^{- \text {-lime }}\right)$, magnesium $(-\mathrm{Mg})$, magnesium without lime $\left(-\mathrm{Mg}^{\text {-lime }}\right)$, sulfur $(-\mathrm{S})$, boron $(-\mathrm{B})$, copper $(-\mathrm{Cu})$, manganese $(-\mathrm{Mn})$ and zinc $(-\mathrm{Zn})$.

Liming was performed with the criterion of base saturation in sufficient quantity to raise the base saturation up to $60 \%$ (Viégas e Botelho 2010) using dolomitic limestone with $32 \%$ of $\mathrm{CaO}, 14 \%$ of $\mathrm{MgO}$, NP of $67 \%$ and RPTN (relative power of total neutralization) of $95 \%$ which was mixed homogeneously with the substrate and incubated for a period of 30 days. After incubation, two assai palm seedlings averaging $10 \mathrm{~cm}$ in height and with two pairs of leaves were planted in plastic containers with $5 \mathrm{~kg}$ of air-dried fine earth (ADFE) that had been sieved with a $4 \mathrm{~mm}$ sieve. Thinning of seedlings for homogenization took place 45 days after planting. Seedlings were grown from seeds of the new cultivar BRS-Pai d'égua developed by Embrapa Amazônia Oriental (to be released).

The seeds were sown in seedbeds containing a substrate of organic soil, sawdust and aged cattle manure in the ratio of 3:1:1. After 45 days all the plantings were provided mineral fertilizer in accordance with the treatments, taking into account the missing element technique, with the following doses according to Viégas (2009), with their respective sources of salts pure for analysis: $\mathrm{N}=100 \mathrm{mg} \mathrm{kg}^{-1}$ of soil-CO $\left(\mathrm{NH}_{2}\right)_{2} ; \mathrm{P}=50 \mathrm{mg} \mathrm{kg} \mathrm{g}^{-1}$ of soil- $\mathrm{NaH}_{2} \mathrm{PO}_{4} ; \mathrm{K}=90 \mathrm{mg} \mathrm{kg}{ }^{-1}$ of soil- $\mathrm{KCl} ; \mathrm{Ca}=30 \mathrm{mg} \mathrm{kg}^{-1}$ of soil- $\mathrm{CaCl}_{2} ; \mathrm{Mg}=30 \mathrm{mg} \mathrm{kg}$-1 of soil- $\mathrm{MgCl}_{2} ; \mathrm{S}=$ $7.5 \mathrm{mg} \mathrm{kg}{ }^{-1}$ of soil- $\mathrm{NaSO}_{4} ; \mathrm{B}=1.2 \mathrm{mg} \mathrm{kg}^{-1}$ of soil- $\mathrm{H}_{3} \mathrm{BO}_{3} ; \mathrm{Cu}=1.0 \mathrm{mg} \mathrm{kg}{ }^{-1}$ of soil-CuSO $4 ; \mathrm{Mn}=4 \mathrm{mg} \mathrm{kg}^{-1}$ of soil- $\mathrm{MnSO}_{4} ; \mathrm{Zn}=5 \mathrm{mg} \mathrm{kg}^{-1}$ of soil- $\mathrm{ZnSO}_{4}$.

Fertilizer containing nitrogen and potassium was applied 45, 90 and 150 days after planting. The soil was irrigated with distilled water while employing the method of weighing the vessel to maintain about $80 \%$ saturation. Plant height, circumference of the stem $2.5 \mathrm{~cm}$ from the substrate, number and size (length and width of leaflets) of the leaves were measured.

The data collection was performed in the eighth month after planting, separating the leaflets, petiol, stem and roots. The separate parts were packed in paper bags, identified and placed in a forced circulation oven with a temperature of $70{ }^{\circ} \mathrm{C}$ until a constant mass was reached, at which point the dried material was weighed and ground in a Wiley-type mill in order to determine the nutrient content. The relative growth of the aerial part $(\mathrm{RGA})$ was calculated using the formula: RGA $(\%)=($ D.M.N.O./D.M.C.T. $) \times 100$, where: D.M.N.O. $=$ total dry mass of aerial part for each nutrient omission and D.M.C.T. = total dry mas of aerial part obtained for the complete treatment. The calculation of leaf area (LA) was adapted from Clement and Bovi (2000) as follows: LA $\left(\mathrm{m}^{2}\right)=(\mathrm{L} \times \mathrm{W}) \times 0.535$, where, $\mathrm{L}=$ leaf length, $\mathrm{W}=$ leaf width and $0.535=$ constant adjusting the shape of a 
rectangle to the shape of a leaf. The determination of macro- and micro-nutrients of the leaves was performed according to Embrapa (2010).

An analysis of variance was performed on the data for the following variables: plant height, diameter of stipe at $2.5 \mathrm{~cm}$ from the substrate, leaf dry mass production, stipe dry mass production, leaf area e content and accumulation of macro and micronutrients following Pimentel Gomes (1990). To determine the accumulation of nutrients, the content $\mathrm{g} \mathrm{kg}^{-1}$ of each nutrient was multiplied by leaf dry mass.

For the analysis of variance, Dunnett's test was used to compare the means for the treatments to that of the complete treatment, and the Scott-Knott test was used for comparisons between treatments, both at the level of $5 \%$ probability. Analyses were performed using the statistical software Action ${ }^{\circledR}$.

\section{Results}

\subsection{Growth and Production of Dry Mass}

The results of parameters of growth and production of dry mass as a function of treatments are shown in Table 1.

Table 2. Plant Height (PH), Stipe Height (SH), Stipe Diameter (SD), Leaf Dry Mass (LDM), Stipe Dry Mass (SDM), Aerial Dry Mass (ADM), Leaf Area (LA), and Relative Growth of the Aerial Part (RGA) of assai palm seedling grown in clayey Oxisol in function of treatments

\begin{tabular}{|c|c|c|c|c|c|c|c|c|}
\hline Treatments & $\mathrm{PH}(\mathrm{cm})$ & $\mathrm{SH}(\mathrm{cm})$ & $\mathrm{SD}(\mathrm{mm})$ & LDM (g) & SDM (g) & $\mathrm{ADM}(\mathrm{g})$ & $\mathrm{LA}\left(\mathrm{cm}^{2}\right)$ & RGA (\%) \\
\hline Complete & $62.20 \mathrm{a}$ & $17.40 \mathrm{~b}$ & $13.69 \mathrm{~b}$ & $8.00 \mathrm{a}$ & $17.21 \mathrm{a}$ & $25.21 \mathrm{a}$ & $917.36 \mathrm{a}$ & 100.00 \\
\hline Complete $^{\text {-lime }}$ & $52.40 \mathrm{~b}$ & $16.80 \mathrm{~b}$ & $12.69 \mathrm{~b}$ & $6.81 \mathrm{a}$ & $13.33 \mathrm{~b}$ & 20.14 a & $651.94 \mathrm{~b}$ & 74.58 \\
\hline$-\mathrm{N}$ & $47.00 * \mathrm{~b}$ & $12.40 * \mathrm{c}$ & $10.49 * \mathrm{c}$ & $3.31 * b$ & $08.97 * \mathrm{~b}$ & $12.28 * b$ & $561.35^{*} \mathrm{~b}$ & 45.46 \\
\hline$-\mathrm{P}$ & $43.40 * \mathrm{c}$ & $11.60 * \mathrm{c}$ & $09.83 * \mathrm{c}$ & $3.25 * b$ & $07.89 * b$ & $11.14 * b$ & $446.71 * b$ & 41.23 \\
\hline$-K$ & $49.80 * b$ & $15.20 \mathrm{~b}$ & $12.06 \mathrm{~b}$ & $4.78 \mathrm{~b}$ & $07.03 * \mathrm{~b}$ & $11.80 * b$ & $487.30 * \mathrm{~b}$ & 43.71 \\
\hline$-\mathrm{Ca}$ & $55.40 \mathrm{~b}$ & $18.40 \mathrm{a}$ & $13.40 \mathrm{~b}$ & $6.88 \mathrm{a}$ & $18.44 \mathrm{a}$ & $25.32 \mathrm{a}$ & 997.45 a & 93.76 \\
\hline$-\mathrm{Ca}^{\text {-lime }}$ & 58.40 a & $18.20 \mathrm{a}$ & $13.31 \mathrm{~b}$ & $6.97 \mathrm{a}$ & $15.96 \mathrm{a}$ & $22.93 \mathrm{a}$ & 767.19 a & 84.90 \\
\hline$-\mathrm{Mg}$ & $48.80 * \mathrm{~b}$ & $16.80 \mathrm{~b}$ & $12.61 \mathrm{~b}$ & $5.93 \mathrm{a}$ & $10.70 \mathrm{~b}$ & $16.64 \mathrm{~b}$ & $601.99 \mathrm{~b}$ & 61.60 \\
\hline$-\mathrm{Mg}^{- \text {-lime }}$ & $54.20 \mathrm{~b}$ & $19.20 \mathrm{a}$ & $12.77 \mathrm{~b}$ & $5.37 \mathrm{a}$ & $10.25 \mathrm{~b}$ & $15.63 * b$ & $952.98 \mathrm{a}$ & 57.86 \\
\hline$-\mathrm{S}$ & $62.60 \mathrm{a}$ & $21.00 \mathrm{a}$ & $15.67 \mathrm{a}$ & $8.45 \mathrm{a}$ & $21.62 \mathrm{a}$ & 30.07 a & $830.93 \mathrm{a}$ & 111.34 \\
\hline$-B$ & 57.60 a & $18.00 \mathrm{a}$ & $13.96 \mathrm{~b}$ & $6.97 \mathrm{a}$ & $20.05 \mathrm{a}$ & $27.02 \mathrm{a}$ & 939.19 a & 100.05 \\
\hline$-\mathrm{Cu}$ & $51.40 \mathrm{~b}$ & $18.60 \mathrm{a}$ & $12.54 \mathrm{~b}$ & $7.05 \mathrm{a}$ & $15.64 \mathrm{a}$ & $22.69 \mathrm{a}$ & 934.26 a & 84.00 \\
\hline$-\mathrm{Mn}$ & $61.80 \mathrm{a}$ & $19.20 \mathrm{a}$ & $13.36 \mathrm{~b}$ & $7.48 \mathrm{a}$ & $19.49 \mathrm{a}$ & $26.97 \mathrm{a}$ & 895.11 a & 99.86 \\
\hline$-Z n$ & $55.00 \mathrm{~b}$ & $18.20 \mathrm{a}$ & $15.07 \mathrm{a}$ & $8.28 \mathrm{a}$ & $21.00 \mathrm{a}$ & $29.28 \mathrm{a}$ & $890.49 \mathrm{a}$ & 108.42 \\
\hline Control & $29.40 * d$ & $6.80 * \mathrm{~d}$ & $7.09 * \mathrm{~d}$ & $1.65 * \mathrm{c}$ & $07.62 * b$ & $12.75 * b$ & $310.66^{*} b$ & 34.32 \\
\hline $\mathrm{CV}(\%)$ & 11.9 & 12.0 & 9.9 & 23.8 & 30.1 & 24.5 & 25.8 & 35.0 \\
\hline
\end{tabular}

Note. Means presenting asterisks $\left(^{*}\right)$ differ significantly from the complete treatment in the same column by Dunnett's test $(p<0.05)$. Means followed by the same letters in each column do not differ significantly from each other by the Scott-Knott test $(\mathrm{p}<0.05)$.

Although some treatments had larger average plant heights and height and diameter of the stipe than the complete treatment, none of these differences were statistically significant. The complete and complete ${ }^{- \text {lime }}$ treatments did not differ statistically in these three parameters, whereas the total omission of nutrients in the control showed restricted growth in plant height of $52.7 \%$; stipe height of $60.9 \%$; and stipe diameter $48.3 \%$ relative to the complete treatment.

The individual omissions of $\mathrm{N}, \mathrm{P}, \mathrm{K}$ and $\mathrm{Mg}$ restricted the initial growth of height in the assai palm, and were responsible for decreases relative to the complete treatment of $24.5 \%, 30.2 \%, 20 \%$ and $21.5 \%$, respectively.

The height and diameter of the stipe were only affected by the omissions of $\mathrm{N}, \mathrm{P}$ and $\mathrm{S}$ with $28.7 \%, 33.3 \%$ and $20.7 \%$ reduction in height, respectively, and a $28.4 \%$ reduction in diameter with the omission of $\mathrm{N}$ and $23.4 \%$ with the omission of $\mathrm{P}$, both in relation to the complete treatment.

The absence of fertilizer in the control was responsible for a $52.7 \%$ limit to plant height, $60.9 \%$ limit to stipe height and a $48.3 \%$ limit to stipe diameter. 
The individual omissions of $\mathrm{P}, \mathrm{N}, \mathrm{K}$ and $\mathrm{Mg}^{\text {-lime }}$, were the treatments with the most restricted production of $\mathrm{LDM}$ (Leaf Dry Mass) in relation to the complete treatment with a reduction of $59.4 \%, 58.5 \%, 40.2 \%$ and $32.7 \%$, respectively. The control treatment had the most restricted gain of LDM with 79.3\%.

The individual omissions of N, P and K limit the production of SDM (Stipe Dry Mass) relative to the complete treatment by $44.4 \%, 54.1 \%$ and $59.1 \%$, respectively, whereas the other individual omissions did not differ significantly and the control reduced by $35.5 \%$.

The omission treatments of $\mathrm{N}, \mathrm{P}, \mathrm{K}, \mathrm{Mg}$ and $\mathrm{Mg}^{\text {-lime }}$, limited the gain of ADM (Aerial Dry Mass) in relation to the complete treatment with reductions to $48.9 \%, 55.8 \%, 53.1 \%, 33.9 \%$ and $38 \%$, respectively. The control treatment decreased the gain of $49.4 \%$. The production of ADM in all of the another treatments was statistically significant equal the complete treatment.

The LA (Leaf Area) was restricted by the individual omission of N, P and $\mathrm{K}$ by $38.9 \%, 50.2 \%$ and $46.9 \%$ respectively, and the control reduced by $66.2 \%$.

The growth of RGA (Relative Growth of the Aerial Part) was most limited by the individual omission of P which reduced it by $58.8 \%$, by $\mathrm{K}$ to $56.3 \%, \mathrm{~N}$ to $54.5 \%, \mathrm{Mg}^{\text {-lime }}$ by $42.1 \%$, and $\mathrm{Mg}$ by $38.4 \%$, and the omission of all of the nutrients reduced by $52.8 \%$.

\subsection{Nutrient Content and Accumulation}

The nutrient content of the LDM for each treatment is presented in Table 2.

Table 3. Contents of macronutrients $\left(\mathrm{g} \mathrm{kg}^{-1}\right)$ and micronutrients $\left(\mathrm{mg} \mathrm{kg}^{-1}\right)$ in leaf dry mass of assai palm seedling grown in clayey Oxisol, in function of treatments

\begin{tabular}{|c|c|c|c|c|c|c|c|c|c|c|}
\hline \multirow{2}{*}{ Treatments } & \multicolumn{10}{|c|}{ Contents } \\
\hline & $\bar{N}$ & $\mathrm{P}$ & $\mathrm{K}$ & $\mathrm{Ca}$ & $\mathrm{Mg}$ & $\mathrm{S}$ & B & $\mathrm{Cu}$ & $\mathrm{Mn}$ & $\mathrm{Zn}$ \\
\hline Complete & $17.10 \mathrm{~b}$ & $1.03 \mathrm{a}$ & $10.22 \mathrm{a}$ & $6.76 \mathrm{~b}$ & $2.34 \mathrm{a}$ & $2.71 \mathrm{c}$ & $32.45 \mathrm{~b}$ & $8.29 \mathrm{~b}$ & $332.42 \mathrm{~b}$ & $133.11 \mathrm{~b}$ \\
\hline Complete -lime $^{\text {. }}$ & $14.06 \mathrm{c}$ & $1.06 \mathrm{a}$ & $10.28 \mathrm{a}$ & $8.13 \mathrm{a}$ & $2.36 \mathrm{a}$ & $4.42 \mathrm{~b}$ & $35.53 \mathrm{a}$ & $8.35 \mathrm{~b}$ & $152.11 * \mathrm{~d}$ & $123.38 \mathrm{~b}$ \\
\hline$-\mathrm{N}$ & $9.31 * \mathrm{~d}$ & $0.99 \mathrm{a}$ & $11.49 \mathrm{a}$ & $9.13 * \mathrm{a}$ & $1.59 * \mathrm{c}$ & $6.39 * \mathrm{a}$ & $34.88 \mathrm{a}$ & $4.87 * \mathrm{f}$ & $148.14 * \mathrm{~d}$ & $72.64 * \mathrm{c}$ \\
\hline$-\mathrm{P}$ & $18.89 \mathrm{~b}$ & $0.55^{*} \mathrm{~b}$ & $10.71 \mathrm{a}$ & $5.21 \mathrm{~b}$ & $1.21 * \mathrm{~d}$ & $4.68 \mathrm{~b}$ & $32.22 \mathrm{~b}$ & $11.66 * a$ & $409.03 * \mathrm{a}$ & $152.65 \mathrm{a}$ \\
\hline$-\mathrm{K}$ & $15.76 \mathrm{c}$ & $1.01 \mathrm{a}$ & $4.62 * b$ & $7.86 \mathrm{a}$ & $2.42 \mathrm{a}$ & $4.49 \mathrm{~b}$ & $33.16 \mathrm{~b}$ & $6.34 * \mathrm{~d}$ & $116.16^{*} \mathrm{~d}$ & $106.53 * b$ \\
\hline$-\mathrm{Ca}$ & $15.43 \mathrm{c}$ & $0.93 \mathrm{a}$ & $8.90 \mathrm{a}$ & $8.11 \mathrm{a}$ & $1.81 * \mathrm{c}$ & $2.64 \mathrm{c}$ & $37.98 * a$ & $6.19 * \mathrm{~d}$ & $166.90 * \mathrm{~d}$ & $117.84 \mathrm{~b}$ \\
\hline$-\mathrm{Ca}^{- \text {-lime }}$ & $14.88 \mathrm{c}$ & $1.06 \mathrm{a}$ & $10.95 \mathrm{a}$ & $5.90 \mathrm{~b}$ & $2.31 \mathrm{a}$ & $2.69 \mathrm{c}$ & $33.14 \mathrm{~b}$ & $7.15^{*} \mathrm{c}$ & $212.39 * \mathrm{c}$ & $107.63 * b$ \\
\hline$-\mathrm{Mg}$ & $17.25 \mathrm{~b}$ & $1.08 \mathrm{a}$ & $11.85 \mathrm{a}$ & $8.70 * \mathrm{a}$ & $2.45 \mathrm{a}$ & $3.49 \mathrm{c}$ & $25.75 * \mathrm{c}$ & $6.48^{*} \mathrm{~d}$ & $206.77 * \mathrm{c}$ & $90.18 * \mathrm{c}$ \\
\hline$-\mathrm{Mg}^{- \text {lime }}$ & $21.52 * \mathrm{a}$ & $1.10 \mathrm{a}$ & $9.08 \mathrm{a}$ & $6.04 \mathrm{~b}$ & $1.57 * \mathrm{c}$ & $2.57 \mathrm{c}$ & $36.19 \mathrm{a}$ & $6.35^{*} \mathrm{~d}$ & $246.90 * \mathrm{c}$ & $158.13 \mathrm{a}$ \\
\hline$-\mathrm{S}$ & $14.23 \mathrm{c}$ & $0.97 \mathrm{a}$ & $9.80 \mathrm{a}$ & $7.72 \mathrm{a}$ & $2.01 \mathrm{~b}$ & $2.46 \mathrm{c}$ & $31.17 \mathrm{~b}$ & $6.39 * \mathrm{~d}$ & $139.54 * \mathrm{~d}$ & $122.51 \mathrm{~b}$ \\
\hline$-B$ & $14.40 \mathrm{c}$ & 0.99 a & $9.98 \mathrm{a}$ & $7.65 \mathrm{a}$ & $2.08 \mathrm{~b}$ & $2.84 \mathrm{c}$ & $27.49 \mathrm{c}$ & $6.04 * \mathrm{~d}$ & $153.62 * \mathrm{~d}$ & $123.27 \mathrm{~b}$ \\
\hline$-\mathrm{Cu}$ & $14.23 \mathrm{c}$ & $1.03 \mathrm{a}$ & $9.62 \mathrm{a}$ & $6.33 \mathrm{~b}$ & $2.35 \mathrm{a}$ & $3.43 \mathrm{c}$ & $34.10 \mathrm{~b}$ & $4.65^{*} \mathrm{f}$ & $129.57 * \mathrm{~d}$ & $125.49 \mathrm{~b}$ \\
\hline$-\mathrm{Mn}$ & $16.86 \mathrm{~b}$ & $1.05 \mathrm{a}$ & $9.14 \mathrm{a}$ & $8.19 \mathrm{a}$ & $1.97 \mathrm{~b}$ & $3.95 \mathrm{~b}$ & $33.00 \mathrm{~b}$ & $6.42 * d$ & $132.13 * \mathrm{~d}$ & $86.64 * \mathrm{c}$ \\
\hline$-Z n$ & $15.27 \mathrm{c}$ & $1.11 \mathrm{a}$ & $11.25 \mathrm{a}$ & $8.30 \mathrm{a}$ & $1.69 * \mathrm{c}$ & $2.71 \mathrm{c}$ & $27.94 \mathrm{c}$ & $5.45^{*} \mathrm{e}$ & $141.75 * \mathrm{~d}$ & $55.98 * \mathrm{~d}$ \\
\hline Control & $14.96 \mathrm{c}$ & $0.44 * b$ & $6.79 * b$ & $6.07 \mathrm{~b}$ & $1.58 * \mathrm{c}$ & $3.08 \mathrm{c}$ & $32.14 \mathrm{~b}$ & $6.55^{*} \mathrm{~d}$ & $123.19 * \mathrm{~d}$ & $56.42 * \mathrm{~d}$ \\
\hline $\mathrm{CV}(\%)$ & 13.48 & 14.42 & 21.17 & 13.54 & 12.94 & 33.18 & 9.34 & 6.72 & 20.74 & 13.01 \\
\hline
\end{tabular}

Note. Means presenting asterisks $\left(^{*}\right)$ differ significantly from the complete treatment in the same column by Dunnett's test $(\mathrm{p}<0.05)$. Means followed by the same letters in each column do not differ significantly from each other by the Scott-Knott test $(\mathrm{p}<0.05)$.

In general, the individual omission treatments caused a reduction in the content of the nutrient being omitted relative to the complete treatment.

The plants of the treatment with the omission of $\mathrm{N}$ were the only ones to experience limited absorption with a content of $45.5 \%$ less than the complete treatment, while the omission of $\mathrm{Mg}^{\text {-lime }}$ stimulated the absorption of $\mathrm{N}$ by $25.9 \%$. The content of $\mathrm{P}$ was also limited only by the treatment omitting it and the control with $46.6 \%$ and $57.2 \%$ compared to the complete treatment, respectively. The content of $\mathrm{K}$ in LDM was limited by the omission of itself and the control by $54.7 \%$ and $33.5 \%$ compared to the complete treatment, respectively. The content of $\mathrm{Ca}$ was stimulated by the omission treatments of $\mathrm{N}$ and $\mathrm{Mg}^{\text {-lime }}$, being greater than complete treatment by $35 \%$ and $28.5 \%$, respectively. 
The content of $\mathrm{Mg}$ in the complete treatment of $2.34 \mathrm{~g} \mathrm{~kg}^{-1}$ was limited in relation to the following treatments in decreasing order: $\mathrm{P}>\mathrm{Mg}^{\text {-lime }}>$ Control $>\mathrm{N}>\mathrm{Zn}>\mathrm{Ca}$, with 48.1\%, 32.6\%, 32.6\%, 31.7\%, 27.5\% and 22.7\%, respectively.

The content of $\mathrm{S}$ was $2.71 \mathrm{~g} \mathrm{~kg}^{-1}$ and had its absorption highly stimulated by the omission of $\mathrm{N}$ to $132.3 \%$ over the complete treatment. It was not statistically affected by any other treatment.

The absorption of $\mathrm{Cu}$ was limited in all of the individual omission treatments, with an average reduction in relation to the complete treatment of $26.8 \%$, with a minimum reduction with the omission of $\mathrm{Ca}^{\text {-lime }}$ of $13.7 \%$ and a maximum of $43.9 \%$ in the omission of the nutrient itself. The treatments in decreasing order of $\mathrm{Cu}$ absorption were: $\mathrm{Cu}>\mathrm{N}>\mathrm{Zn}>\mathrm{B}>\mathrm{Ca}>\mathrm{K}>\mathrm{Mg}^{\text {-lime }}>\mathrm{S}>\mathrm{Mn}>\mathrm{Mg}>\mathrm{Control}>\mathrm{Ca}^{\text {-lime }}$. The absorption of this element was favored only buy the omission of $\mathrm{P}$ with $40.5 \%$ compared to the complete treatment.

The content of $\mathrm{Zn}$ was limited in relation to the complete treatment by the following treatments in decreasing order: $\mathrm{Zn}>$ Control $>\mathrm{N}>\mathrm{Mn}>\mathrm{Mg}>\mathrm{K}>\mathrm{Ca}^{\text {-lime }}$, with $57.9 \%, 57.6 \%, 45.4 \%, 34.9 \%, 32.3 \%, 20 \%$ and $19.1 \%$, respectively.

The absorption of Mn was limited in the majority of treatments with an average reduction of $52 \%$ relative to the complete treatment, with the minimum being with the omission of $\mathrm{Mg}^{- \text {lime }}$ with $25.7 \%$ and the maximum of $65 \%$ with the omission of $\mathrm{K}$. The treatments in decreasing order of absorption of $\mathrm{Mn}$ were: $\mathrm{K}>\mathrm{Control}>\mathrm{Cu}>\mathrm{Mn}>$ $\mathrm{S}>\mathrm{Zn}>\mathrm{N}>$ Complete $^{\text {-lime }}>\mathrm{B}>\mathrm{Ca}>\mathrm{Mg}>\mathrm{Ca}^{\text {-lime }}>\mathrm{Mg}^{\text {-lime }}$. The contents of the micronutrients $\mathrm{Cu}, \mathrm{Zn}$ and $\mathrm{Mn}$ had lower values than the complete treatment for the majority of the individual omission treatments.

The decreasing order of the accumulation of all the nutrients in the leaves in relation to the complete treatment were: $\mathrm{N}>\mathrm{K}>\mathrm{Ca}>\mathrm{Mg}>\mathrm{P}>\mathrm{Mn}>\mathrm{Zn}>\mathrm{B}>\mathrm{Cu}>\mathrm{S}$ (Table 3).

Table 4. Accumulation of macro- and micro-nutrients (mg plant $\left.{ }^{-1}\right)$ in leaf dry mass of assai palm seedling grown in clayey Oxisol, in function of treatments

\begin{tabular}{|c|c|c|c|c|c|c|c|c|c|c|}
\hline \multirow{2}{*}{ Treatments } & \multicolumn{10}{|c|}{ Accumulation } \\
\hline & $\mathrm{N}$ & $\mathrm{P}$ & $\mathrm{K}$ & $\mathrm{Ca}$ & $\mathrm{Mg}$ & $\mathrm{S}$ & $\mathrm{B}$ & $\mathrm{Cu}$ & $\mathrm{Mn}$ & $\mathrm{Zn}$ \\
\hline Complete & $139.62 \mathrm{a}$ & $8.38 \mathrm{a}$ & $80.80 \mathrm{a}$ & $52.79 \mathrm{~b}$ & $18.61 \mathrm{a}$ & $0.021 \mathrm{a}$ & $0.257 \mathrm{a}$ & $0.066 \mathrm{a}$ & $2.648 \mathrm{a}$ & $1.068 \mathrm{a}$ \\
\hline Complete $^{\text {-lime }}$ & $94.79 \mathrm{a}$ & $7.23 \mathrm{a}$ & $68.15 \mathrm{a}$ & $54.33 \mathrm{~b}$ & $15.83 \mathrm{a}$ & $0.030 \mathrm{a}$ & $0.241 \mathrm{a}$ & $0.057 \mathrm{a}$ & $1.042 * b$ & $0.803 \mathrm{~b}$ \\
\hline$-\mathrm{N}$ & $30.91 * b$ & $3.25 * \mathrm{c}$ & $38.02 * b$ & $30.08 * \mathrm{c}$ & $5.22 * \mathrm{c}$ & $0.021 \mathrm{a}$ & $0.115 * b$ & $0.016^{*} \mathrm{~d}$ & $0.495^{*} \mathrm{c}$ & $0.243 * \mathrm{~d}$ \\
\hline$-\mathrm{P}$ & $61.83 * b$ & $1.80 * \mathrm{c}$ & $35.22 * b$ & $16.98 * \mathrm{~d}$ & $3.93 * \mathrm{c}$ & $0.015 \mathrm{a}$ & $0.105^{*} \mathrm{~b}$ & $0.038 * b$ & $1.315^{*} \mathrm{~b}$ & $0.489 * \mathrm{c}$ \\
\hline$-K$ & $78.88 * \mathrm{a}$ & $4.80 * b$ & $20.93 * \mathrm{c}$ & $37.15 \mathrm{c}$ & $12.22 * \mathrm{a}$ & $0.022 \mathrm{a}$ & $0.157 * b$ & $0.030 * \mathrm{c}$ & $0.543^{*} \mathrm{c}$ & $0.510 * \mathrm{c}$ \\
\hline$-\mathrm{Ca}$ & $106.53 \mathrm{a}$ & $6.37 \mathrm{~b}$ & $60.89 \mathrm{a}$ & $56.46 \mathrm{~b}$ & $12.52 * \mathrm{a}$ & $0.018 \mathrm{a}$ & $0.262 \mathrm{a}$ & $0.043 * b$ & $1.164 * b$ & $0.811 \mathrm{~b}$ \\
\hline$-\mathrm{Ca}^{- \text {lime }}$ & $104.59 a$ & $7.36 \mathrm{a}$ & $76.83 \mathrm{a}$ & $41.15 \mathrm{~b}$ & $16.11 \mathrm{a}$ & $0.019 \mathrm{a}$ & $0.230 \mathrm{a}$ & $0.050 \mathrm{~b}$ & $1.487^{*} \mathrm{~b}$ & $0.750 * b$ \\
\hline$-\mathrm{Mg}$ & $102.64 \mathrm{a}$ & $6.37 \mathrm{~b}$ & $70.22 \mathrm{a}$ & $51.57 \mathrm{~b}$ & $14.48 \mathrm{a}$ & $0.021 \mathrm{a}$ & $0.153^{*} \mathrm{~b}$ & $0.039 * b$ & $1.213 * b$ & $0.536^{*} \mathrm{c}$ \\
\hline$-\mathrm{Mg}^{- \text {lime }}$ & $115.78 \mathrm{a}$ & $5.88 \mathrm{~b}$ & $50.04 \mathrm{~b}$ & $32.62 * \mathrm{c}$ & $8.41 * b$ & $0.015 \mathrm{a}$ & $0.192 \mathrm{a}$ & $0.034 * \mathrm{c}$ & $1.325^{*} \mathrm{~b}$ & $0.850 \mathrm{~b}$ \\
\hline$-\mathrm{S}$ & $119.05 \mathrm{a}$ & $8.15 \mathrm{a}$ & $82.27 \mathrm{a}$ & $65.61 \mathrm{a}$ & $17.17 \mathrm{a}$ & $0.022 \mathrm{a}$ & $0.267 \mathrm{a}$ & $0.054 \mathrm{a}$ & $1.173 * b$ & $1.038 \mathrm{a}$ \\
\hline$-B$ & $99.82 \mathrm{a}$ & $6.88 \mathrm{~b}$ & $69.64 \mathrm{a}$ & $53.34 \mathrm{~b}$ & $14.56 \mathrm{a}$ & $0.020 \mathrm{a}$ & $0.192 \mathrm{a}$ & $0.042 * b$ & $1.062 * b$ & $0.861 \mathrm{~b}$ \\
\hline$-\mathrm{Cu}$ & $99.97 \mathrm{a}$ & $7.25 \mathrm{a}$ & $67.37 \mathrm{a}$ & $44.86 \mathrm{~b}$ & $16.42 \mathrm{a}$ & $0.024 \mathrm{a}$ & $0.240 \mathrm{a}$ & $0.033^{*} \mathrm{c}$ & $0.903 * b$ & $0.885 \mathrm{~b}$ \\
\hline$-M n$ & $126.00 \mathrm{a}$ & $7.89 \mathrm{a}$ & $68.50 \mathrm{a}$ & $61.23 \mathrm{a}$ & $14.68 \mathrm{a}$ & $0.029 \mathrm{a}$ & $0.247 \mathrm{a}$ & $0.048 \mathrm{~b}$ & $0.985^{*} \mathrm{~b}$ & $0.648 * b$ \\
\hline$-Z n$ & $122.57 \mathrm{a}$ & $9.17 \mathrm{a}$ & $96.60 \mathrm{a}$ & $66.52 \mathrm{a}$ & $13.95 \mathrm{a}$ & $0.023 \mathrm{a}$ & $0.232 \mathrm{a}$ & $0.045^{*} \mathrm{~b}$ & $1.155^{*} \mathrm{~b}$ & $0.466^{*} \mathrm{c}$ \\
\hline Control & $24.51 * b$ & $0.72 * \mathrm{c}$ & $11.21 * \mathrm{c}$ & $9.99 * \mathrm{~d}$ & $2.60 * \mathrm{c}$ & $0.005^{*} \mathrm{a}$ & $0.053 * \mathrm{c}$ & $0.011 * \mathrm{~d}$ & $0.202 * \mathrm{c}$ & $0.093 * \mathrm{~d}$ \\
\hline $\mathrm{CV}(\%)$ & 29.14 & 26.60 & 32.32 & 24.91 & 26.86 & 43.99 & 24.93 & 25.46 & 29.36 & 26.38 \\
\hline
\end{tabular}

Note. Means presenting asterisks (*) differ significantly from the complete treatment in the same column by Dunnett's test $(\mathrm{p}<0.05)$. Means followed by the same letters in each column do not differ significantly from each other by the Scott-Knott test $(\mathrm{p}<0.05)$.

\section{Discussion}

\subsection{Growth and Production of Dry Mass}

The omission of all of the nutrients from the control restricted growth of plant height by $52.7 \%$, stipe height by $60.9 \%$ and stipe diameter by $48.3 \%$ in relation to the complete treatment. These results demonstrate the importance of the application of nutrients to the development of assai palm of this variety being cultivated on clayey Oxisol. 
The individual omissions of $\mathrm{N}, \mathrm{P}, \mathrm{K}$ and $\mathrm{Mg}$ restricted the initial in height of assai palm, corroborating the findings of Viégas et al. (2004) who demonstrated that the individual omissions of $\mathrm{N}, \mathrm{P}, \mathrm{K}$ and $\mathrm{Mg}$ in medium-texture Oxisol limited the height of assai palm seedling by $35.4 \% ; 38.5 \% ; 20 \%$; and $6 \%$, respectively. Viégas et al. (2008), working with assai palm seedling growth as a function of the omission of nutrients in nutrient solution, found reductions in growth of height in assai palm plants with their omissions of $\mathrm{N}$ by $63.1 \%$, $\mathrm{K}$ by $52.5 \%$, Mg by $51 \%$ and $\mathrm{P}$ by $48.1 \%$, and reductions in treatments that were not detected in the present study, such as $\mathrm{K}$ with a reduction of $52.5 \%$, B with $50.1 \%$, S with $39.2 \%$ and $\mathrm{Ca}$ with $14.9 \%$, compared to the complete treatment. That these limitations were not detected in the present study is understandable due to the presence of these nutrients in the soil substrate used.

Viégas et al. (2009) demonstrated that the individual omissions of $\mathrm{N}$ and $\mathrm{P}$ in clayey Oxisol limit the growth in height of assai palm. The height of $62.2 \mathrm{~cm}$ achieved with the complete treatment in this experiment is less that the heights reached by the assai palm of Viégas et al. (2008), with $76.7 \mathrm{~cm}$ and Viégas et al. (2004) with $117 \mathrm{~cm}$, however, these differences could be related to both the duration of the experiments and the genetic pattern of the studied varieties.

The restrictions to dry weight gain observed here are consistent with other research on assai palm. With assai palm growing on a substrate of medium-texture Oxisol, Viégas et al. (2004) found reduced LDM, SDM and ADM for plants with individual omission treatments of $\mathrm{N}, \mathrm{P}, \mathrm{K}$ and $\mathrm{Mg}$ in relation to the complete treatment. Also, Haag et al. (1992) found that assai palm seedlings cultivated on a nutritive solution exhibited a decrease in LDM with the omission of $\mathrm{N}, \mathrm{P}, \mathrm{K}$ and $\mathrm{Mg}$ and $\mathrm{S}$ with $31.2 \%, 13.0 \%, 24.7 \%, 37.7 \%$, respectively.

These studies also point out the importance of Ca and $\mathrm{S}$ for gain in LDM. Viégas et al. (2004) reported that the omission of $\mathrm{Ca}$ caused a reduction of $9.57 \%$ and Haag et al. (1992) reported that the absence of this element determined a reduction of $27.21 \%$ and for S $13 \%$. In addition to this, other studies have shown that the absence of these elements can be limiting factors in the gain of dry mass by assai palm seedlings (Viégas et al., 2008, 2009), however, the omissions of these nutrients did not affect the gain of LDM in the present study indicating that the substrate used had sufficient amounts for the assai palm variety studied to gain mass as a function of age.

The restriction of LA of assai palm and the decreasing RGA corroborate Viégas et al. (2008) who found that the number of leaves of assai palm in treatments with individual omissions of $\mathrm{N}, \mathrm{P}$ and $\mathrm{K}$ was significantly reduced in relation to the complete treatment in order of 50\%, 33\% and 30\%, respectively, and Viégas et al. (2009) showed relative growth to be most affected by the omission of $\mathrm{P}$, with a reduction of $55.23 \%$, of $\mathrm{N}$ with $42.42 \%$, of $\mathrm{K}$ with $36.88 \%$ and the omission of Mg with $26.4 \%$. Haag et al. (1992) showed that the omission of nutrients interferes with the production of dry mass in the following descending order: $\mathrm{K}>\mathrm{Mg}>\mathrm{P}>\mathrm{N}>\mathrm{Ca}>\mathrm{S}>\mathrm{B}$.

\subsection{Nutrient Content and Accumulation}

In the complete treatment, the descending sequence of macronutrient $\left(\mathrm{g} \mathrm{kg}^{-1}\right)$ content in LDM was $\mathrm{N}>\mathrm{K}>\mathrm{Ca}>$ $\mathrm{S}>\mathrm{Mg}>\mathrm{P}$, and micronutrient $\left(\mathrm{mg} \mathrm{kg}^{-1}\right)$ content was $\mathrm{Mn}>\mathrm{Zn}>\mathrm{B}>\mathrm{Cu}$. Studying the peach palm seedling (Bactris gasipaes Kunth), a plant of Amazônia and of the same botanical family as assai palm, Fernandes et al. (2013) found that individuals grown in complete solution the decreasing sequence of macronutrients as content in the leaves and stem to be $\mathrm{N}>\mathrm{K}>\mathrm{Ca}>\mathrm{P}>\mathrm{Mg}>\mathrm{S}$. Viégas et al. (2009) found a sequence of macronutrients in $\mathrm{LDM}$ to be $\mathrm{N}>\mathrm{Ca}>\mathrm{K}>\mathrm{Mg}>\mathrm{S}>\mathrm{P}$.

The content of $\mathrm{N}$ in LDM of the complete treatment of $17.10 \mathrm{~g} \mathrm{~kg}^{-1}$ was higher than those determined in similar experiments with assai palm by Viégas et al. (2009) who reported $15.67 \mathrm{~g} \mathrm{~kg}^{-1}$ of $\mathrm{N}$ in Oxisol; Haag et al. (1992) reported $16.6 \mathrm{~g} \mathrm{~kg}^{-1}$ of $\mathrm{N}$, but lower than Gonçalves (2004) who reported $19.4 \mathrm{~g} \mathrm{~kg}^{-1}$, and Silva and Falcão (2002), researching the nutritional limitations of peach palm seedlings, obtained poorly developed plants in the $\mathrm{N}$ omission treatment, leaf content of $30.7 \mathrm{~g} \mathrm{~kg}^{-1}$ in the complete treatment and $10.1 \mathrm{~g} \mathrm{~kg}^{-1}$ with the omission of the nutrient itself. The stimulation of $\mathrm{N}$ absorption by omitting $\mathrm{Mg}^{\text {-lime }}$ was also observed by Silva and Falcão (2002) where the increase in leaf $\mathrm{N}$ content in peach palm by the omission of $\mathrm{Mg}$ was on the order of $5.9 \%$.

The leaf content of $\mathrm{P}$ of the complete treatment was $1.03 \mathrm{~g} \mathrm{~kg}^{-1}$ and is consistent with that reported by Haag et al. (1992) of $1.3 \mathrm{~g} \mathrm{~kg}^{-1}$ and by Gonçalves (2004) of $1.69 \mathrm{~g} \mathrm{~kg}^{-1}$ and higher than that obtained by Viégas et al. (2009) of $0.70 \mathrm{~g} \mathrm{~kg}^{-1}$. The content of $\mathrm{P}$ was limited only by the omission of itself and in the control, with $46.6 \%$ and $57.2 \%$ in relation to the complete treatment, respectively.

The leaf content of $10.22 \mathrm{~g} \mathrm{~kg}^{-1}$ for $\mathrm{K}$ of the complete treatment is 2.9 times higher than that found by Viégas et al. (2009) with assai palm on Yellow Lotosol (3.52 $\mathrm{g} \mathrm{kg}^{-1}$ of $\mathrm{K}$ ), and most consistent with that obtained by Gonçalves (2004) $\left(9.42 \mathrm{~g} \mathrm{~kg}^{-1}\right)$ and less than that obtained by Haag et al. (1992) (19.6 g kg$\left.{ }^{-1}\right)$, both of which 
were using a nutritive solution containing silica as a substrate. The content of $\mathrm{K}$ in the LDM was limited by the omission of the element itself and by the control.

The content of $6.76 \mathrm{~g} \mathrm{~kg}^{-1}$ of Ca is compatible with that obtained by Viégas et al. (2009) who had $6.40 \mathrm{~g} \mathrm{~kg}^{-1} \mathrm{of}$ $\mathrm{Ca}$, and less than that of Silva and Falcão (2002) who had $9.35 \mathrm{~g} \mathrm{~kg}^{-1}$. The content of Ca stimulated by the omission treatments of $\mathrm{N}$ and $\mathrm{Mg}^{\text {-lime }}$ were higher than the complete treatment.

The leaf content of Mg from the complete treatment was close to that obtained by Viégas et al. (2009), who reported $2.2 \mathrm{~g} \mathrm{~kg}^{-1}$ of Mg in the complete treatment, and also close to that obtained by Haag et al. (1992) using nutritive solution.

The contents of $\mathrm{S}$ obtained were higher than those obtained by Viégas et al. (2009) of $1.35 \mathrm{~g} \mathrm{~kg}^{-1}$. The relationship between the contents of $\mathrm{S}$ and $\mathrm{N}$ is related to the concentration of reducing sugars, accumulation of carbohydrates and the synthesis of proteins (Hawkesford, 2000), because of the lower conversion of $\mathrm{N}$ into an organic form (Prado et al., 2007).

The content of the micronutrients $\mathrm{Cu}, \mathrm{Zn}$ and $\mathrm{Mn}$ were lower than the complete treatment for the majority of individual omission treatments. This fact can be attributed to the liming, which augments the $\mathrm{pH}$ of the soil and diminishing the availability of these micronutrients thus affecting their absorption by plants (Malavolta, 2006). Viégas et al. (2009) demonstrated Mn as the most limiting micronutrient for the growth of assai palm in medium textured Oxisol, however, the present study on loamy Oxisol did not obtain results that attest to the importance of this micronutrient, although both studies had almost the same content of $\mathrm{Mn}$ in the soil, Viégas et al. (2009) with $3.5 \mathrm{mg} \mathrm{dm}^{-3}$ and the present study with $3.6 \mathrm{mg} \mathrm{dm}^{-3}$.

The content obtained for B in the complete treatment was $32.45 \mathrm{mg} \mathrm{kg}^{-1}$, equivalent to that obtained by Viégas et al. (2009) who had $31.34 \mathrm{mg} \mathrm{kg}^{-1}$, and less than that determined by Haag et al. (1992), with $51 \mathrm{mg} \mathrm{kg}^{-1}$, in their complete treatments. The content of B was diminished with the omission of $\mathrm{Mg}$ to $20.7 \%$, and was favored by $17 \%$ with the omission of $\mathrm{Ca}$.

Viégas et al. (2004), studied the effect of doses of boron on growth of assai palm plants, concluding that the estimated optimal dose was $2.3 \mathrm{mg} \mathrm{L}^{-1}$ and that higher than $2.5 \mathrm{mg} \mathrm{L}^{-1}$ had depressive effect on growth. Other studies point to B as limiting the development of palm trees in Amazônia (Viégas et al., 2009; Rocha et al., 2015).

The study of the total accumulation of nutrients in the leaves shows that the most needed nutrients by the variety of assai palm studied are N, K and Ca. From cultivating assai palm BRS-Pará on Oxisol, Viégas et al. (2009) attested to the accumulation of macronutrients in the decreasing order of $\mathrm{N}>\mathrm{Ca}>\mathrm{K}>\mathrm{Mg}>\mathrm{S}>\mathrm{P}$, while Fernandes et al. (2013), studying peach palm, obtained in decreasing order of total accumulation of macronutrients of: $\mathrm{N}>\mathrm{K}>\mathrm{Ca}>\mathrm{P}>\mathrm{Mg}>\mathrm{S}>\mathrm{Na}$. These data show that $\mathrm{N}, \mathrm{K}, \mathrm{Ca}$ and $\mathrm{P}$ are nutrients most accumulated early in development and not only for assai palm but for other plants of the family Arecaceae.

\section{Conclusions}

The most limiting nutrients for the growth of assai palm seedling of the variety Pai d'égua in clayey Oxisol are $\mathrm{N}, \mathrm{P}, \mathrm{Mg}$ and $\mathrm{S}$. The production of dry aerial mass is affected by omission in decreasing order: $\mathrm{N}>\mathrm{P}>\mathrm{K}>\mathrm{Mg}$. Leaf area is restricted by the omission of individual nutrients in the order $\mathrm{Ca}>\mathrm{N}>\mathrm{P}>\mathrm{K}>\mathrm{Mg}>\mathrm{Zn}$ and the nutrients most required by assai palm, as evidenced by the content and accumulation of the nutrients in the leaf dry mass, are N, K, and Ca.

\section{References}

Armenguad, P., Sulpice, R., Miller, A. J., Stitt, M.; Amtmann, A., \& Gibon, Y. (2009). Multilevel analysis of primary metabolism provides new insights into the role of potassium nutrition for glycolysis and nitrogen assimilation in Arabidopsis roots. Plant Physiology, 150, 772-785. https://doi.org/10.1104/pp.108.133629

Bovi, M. L. A., Godoy, J. R. G., \& Spiering, S. H. (2002). Respostas de crescimento de pupunheira à adubação NPK. Scientia Agricola, 59(1), 161-166.

Clement, C. R., \& Bovi, M. L. A. (2000). Padronização de medidas de crescimento e produção em experimentos com pupunheira para palmito. Acta Amazônica, 30(3), 349-362. https://doi.org/10.1590/1809-43922000 303362

Embrapa. (2010). Métodos de análises bromatológicas de alimentos: Métodos físicos, químicos e bromatológicos. Embrapa Clima Temperado (p. 177). Pelotas, RS. 
Embrapa. (2013). Centro Nacional de Pesquisa de Solos (p. 342). Sistema Brasileiro de Classificação de Solos. Brasília, DF.

Fernandes, A. R., Matos, G. S. B., \& Carvalho, J. G. (2013). Deficiências nutricionais de macronutrientes e sódio em mudas de pupunheira. Revista Brasileira de Fruticultura (Impresso), 35, 1178-1189. https://doi.org/ 10.1590/S0100-29452013000400029

Gonçalves, A. S. (2004). Crescimento, composição mineral e sintomas visuais de deficiências de macronutrientes e boro, em plantas de açaizeiro (Euterpe oleracea Mart.) (Dissertação de Mestrado. Universidade Federal Rural da Amazôni).

Haag, H. P., Silva Filho, N. L., \& Carmello, Q. A. C. (1992). Carência de macronutrientes e de boro em plantas de açaí (Euterpe oleracea Mart.). Congresso Nacional Sobre Essências Nativa, São Paulo (pp. 477-479). Anais... São Paulo: Unipress.

Hawkesford, M. J. (2000). Plant response to Sulphur deficiency and the genetic manipulation of sulphate transporters to improve S-utilization efficiency. Journal of Experimental Botany, 51, 131-138. https://doi.org/10.1093/jxb/51.342.131

IBGE. (2015). Levantamento Sistemático da Produção Agrícola Paraense (LSPA/IBGE). Belém-PA.

Laviola, B. G., \& Dias, L. A. S. (2008). Teor e acúmulo de nutrientes em folhas e frutos de pinhão-manso. Revista Brasileira de Ciência do Solo, 32(5) 1969-1975. https://doi.org/10.1590/S0100-068320080005 00018

Malavolta, E. (1980). Elementos de nutrição mineral de plantas (p. 251). São Paulo: Editora Agronômica Ceres.

Malavolta, E. (2006). Manual de nutrição de plantas (p. 638). Agronômica Ceres, São Paulo.

Menezes, E. M. S., Torres, A. T., \& Srur, A. U. S. (2008). Valor nutricional da polpa de açaí (Euterpe oleracea Mart) liofilizada. Acta Amazônica, 38(2), 311-316. https://doi.org/10.1590/S0044-59672008000200014

Miranda, R. S., Suderio, F. B., Sousa, A. F., \& Gomes Filho, E. (2010). Deficiência nutricional em plântulas de feijão-de-corda decorrente da omissão de macro e micronutrientes. Revista Ciência Agronômica, 41(3) 326-333. https://doi.org/10.1590/S1806-66902010000300002

Oliveira, M. S. P., Carvalho, J. E. U., Nascimento, W. M. O., \& Müller, C. H. (2002). Cultivo do açaizeiro para produção de frutos. Belém: Embrapa Amazônia Oriental, Circular Técnica, 26, 17.

Oliveira, L. P., Tavares, G. S., \& Homma A. K. O. (2016). Programa de Desenvolvimento da Cadeia Produtiva do Açaí no Estado do Pará-PROAÇAÍ-PA. Belém, SEDAP.

Pimentel Gomes, F. (1990). Curso de estatística experimental (p. 468). Piracicaba: Nobel.

Prado, R. M., Romualdo, L. M., \& Rozane, D. E. (2007). Omissão de macronutrientes no desenvolvimento e no estado nutricional de plantas de sorgo (cv. BRS 3010) cultivadas em solução nutritiva. Cientifica, 35(2) 122-128.

Rocha, P. L. G., Monnerat, P. H., Pires, A. A., Freitas, M. S. M., \& Marciano, C. R. (2015). Diagnosis of Boron Deficiency in Green Dwarf Coconut Palm. Agricultural Sciences, 6, 164-174. https://doi.org/10.4236/as. 2015.61015

Silva, J. R. A., \& Falcão, N. P. S. (2002). Caracterização de sintomas de carências nutricionais em mudas de pupunheira cultivada em solução nutritiva. Acta Amazônica, 32(4), 529-539. https://doi.org/10.1590/180943922002324539

Viégas I. J. M., Meireles, R. O., Frazão, D. A. C., \& Conceição, H. E. O. (2009). Avaliação da fertilidade de um latossolo amarelo textura média para o cultivo do açaizeiro no estado do Pará. Revista de Ciências Agrárias, $52,23-35$.

Viégas, I. J. M., Frazão, D. A. C., Thomaz, M. A. A., Conceição, H. E. O., \& Pinheiro, E. (2004). Limitações nutricionais para o cultivo do açaizeiro em latossolo amarelo textura média, Estado do Pará. Revista Brasileira de Fruticultura, 26(2) 382-384. https://doi.org/10.1590/S0100-29452004000200052

Viégas, I. J. M., Gonçalves, A. A. S., Frazão, D. A. C., \& Conceição, H. E. O. (2008). Efeitos das omissões de macronutrientes e boro na sintomatologia e crescimento em plantas de açaizeiro (Euterpe oleraceae Mart). Revista de Ciências Agrárias, 50, 129-141.

Viégas, I. J. M., \& Botelho, S. M. (2010). Açaizeiro. In M. S. Cravo, I. J. M. Viégas, \& E. C. Brasil (Eds.), Recomendações de adubação e calagem para o Estado do Pará. Belém, PA: Embrapa Amazônia Oriental. 


\section{Copyrights}

Copyright for this article is retained by the author(s), with first publication rights granted to the journal.

This is an open-access article distributed under the terms and conditions of the Creative Commons Attribution license (http://creativecommons.org/licenses/by/4.0/). 